\title{
COSMAN CITROEN (1881-1935), A MUNICIPAL ADVISORY AND INDEPENDENT ARCHITECT IN SURABAYA
}

\author{
Joko Triwinarto Santoso \\ Department of Architecture, Brawijaya University, \\ Indonesia \\ e-mail: jokotris@yahoo.com,jokotris@ub.ac.id
}

\begin{abstract}
A Dutch architect Cosman Citroen (1881-1935) is known as one of the well-known architects in the Netherlands Indies. In various articles or studies, he was known as the advisory architect of the Surabaya Municipality during his career. However, none of them was able to explain exactly since and until when he occupied the status and also when he underwent a professional career as an independent architect. From this point, it can be drawn which works he produced during his service for the municipality and which ones created as an independent architect.
\end{abstract}

Keywords: Cosman Citroen, municipal advisory architect, independent architect, Surabaya, Dutch colonial architecture

\section{INTRODUCTION}

Cosman Citroen (1881-1935) was one of the most remarkable architects in the Netherlands Indies, especially in Surabaya, as stated by Lemei (1935). His role in this city is so great that a discussion of Dutch colonial architecture in Surabaya cannot be separated from the name of Citroen. If Bandung is considered as the city of C.P. Wolff Schoemaker due to a series of his works and Semarang as that of Thomas Karsten (Berlage, 1931), Surabaya belongs to Citroen because of the bulk of whose design could be found in the city.

However, up to now, it has not been able to find an article or a study that reveals since when Citroen works for the Surabaya Municipality as an advisory architect and for how long he held the status of it. If it is related to his works that are not only buildings owned by the municipality but also private buildings, it will arise a question whether during his status as the municipal architect, he was allowed to serve private clients, or whether all of the private buildings are designed after his service for the municipality ends. In other words, whether during his career in Surabaya since his arrival to this city until his death on May 15, 1935 (Zeeuw, 
2001), Citroen always holds the status as the advisory architect of the Surabaya Municipality. If not, what reasons that lead to terminate the contract. And the last question is which works he designed in each position, as a municipal architect and an independent one. This article will answer a series of these questions.

\section{THEORY / RESEARCH METHODS}

The study was conducted by using a historical descriptive method. Historical data are obtained from archives in the form of Notulen van de Openbare Vergadering van den Gemeenteraad van Soerabaja (Minutes of Public Meetings of the Surabaya City Council) and Gemeentebladen van Soerabaja (Municipal Sheets of Surabaya). The use of both sources is based on the premise that any expenses used to pay Citroen's salaries had to be discussed and decided in the meetings of the City Council as a legislative institution. All of this discussion is recorded in detail in the form of the minutes of the City Council. Furthermore, conclusions and decisions of the City Council are stated in a decree of the Surabaya mayor and written on a municipal sheet.

The two types of materials can be known exactly when Citroen's contract as the advisory architect of the Surabaya Municipality starts and ends. Thus, beyond the time of the contract, Citroen acts as an independent architect or a private one.

\section{RESULTS AND DISCUSSION}

\section{Citroen's Position}

The oldest document revealing a relationship and contract between Citroen and the Municipality of Surabaya and/or its services is a letter from L.J. Schippers, voorzitter (president or chairman) of the Surabaya City Council, No. 2529/16 dated April 10, 1916. The letter asks the Director of Gemeentewerken (Municipal Works) if Citroen's service to the Municipality should be extended or not and for what reasons (Anonymous, April 15, 1916). If the duration of the contract was for one year, Citroen would have worked for the Municipality beginning in April 1915, after he came to Surabaya. He was placed on the NV. Bouwmaatschappij "Kupang" to plan the development of the Kupang area reserved for low-income groups.

Five days later, A. de Mooy Aczn., Director of Municipal Works, informed the president of the City Council in a letter No. 509/1 dated April 15, 1916, that he had several conversations with the Technische Commissie (Commission of Technical) and the Uitbreidingscommissie (Commission of Extension). He was asked to propose Citroen's position. At the time, the Municipal Works Department had taken on many projects, not only projects for city development managed by its branch, i.e. Stadsuitbreiding Bureau (Town Extension Bureau), but also the development of the Surabaya harbour, the extension of the railway network in the city (through co-operation with Staatsspoorwegen or State Railways), the 
improvement of marshy land, projects for rivers, the installation of a drainage system, a sewer system and the provision of affordable housing. With such a heavy workload, the Municipal Works Department was recommended to recruit Citroen or to extend his service with the Municipality. In the last meeting with A. van Dorsten, chairman of the Development Commission, it was decided that Citroen's service would be needed to expand the development plans that had already been decided. His expertise was also requested for the continuation of the new Surabaya Town Hall project. The design needed revision, especially about its dimension (Anonymous, April 15, 1916).

Furthermore, to keep Citroen in his position, the Director of the Municipal Works proposed offering him a salary increase, a decision approved by both the Commission of Technical and the Commission of Extension. The contract stated:

1. salary for Citroen to be $f 500$ per month;

2. if the City Council approved the final design of the Town Hall project, Citroen would receive extra compensation set at $1 \%$ of the building costs; and

3. upon completion of the Town Hall, Citroen would receive additional compensation amounting to 5\% of the building costs for his architectural guidance to be paid in predetermined intervals (Anonymous, April 15, 1916).

The president of the City Council, in a letter to the Director of Municipal Works No. 3541/16 dated May 20, 1916, expressed his disagreement with the proposed contract outlined above. He expressed some objections including:

1. the proposal does not mention Citroen's working hours;

2. the description of Citroen's activities should be determined by the rooimeester (superintendent);

3 . the $1 \%$ bonus should not be given if the design were made during office working hours; and

4. the $5 \%$ compensation should be considered following general regulations for engineers, architects, etc (Anonymous, May 31, 1916).

To respond to the president's concerns, the Director of the Municipal Works sent a letter No. 683/16 dated May 26, 1916. It explained the following:

1. after consultation with Citroen, the working hours were set at 07.00 to 12.00;

2. job descriptions in the April 15, 1916 letter are clear enough. For the development plan of the Municipality, Citroen would collaborate with other civil servants and also with the Commission of Extension established by the City Council;

3. the $1 \%$ bonus of the total Town Hall costs was given because he also received similar compensation for other projects; and

4. extra compensation for the Town Hall construction, which was based on general regulations for engineers and architects, would be discussed personally with Citroen at a later date.

The above conditions would be effective from June 1, 1916, onwards (Anonymous, May 31, 1916).

With slight revisions (working hours from 07.30 to 13.00), the president finally accepted the above proposal and forwarded it to the City Council for approval in a letter No. 3688/16 dated May 27, 1916 (Anonymous, May 31, 1916). 
Four days later, the City Council held a meeting to discuss the decision. This meeting was also attended by A. de Mooy Aczn.

At the meeting, president L.J. Schippers informed the council that a decision, if approved, would be effective from May 1, 1916, onwards (not June 1, 1916), because the previous contract between Citroen and the Municipality ended on April 15, 1916. At the meeting, one of the crucial points discussed was whether or not Citroen was prohibited to practice privately as an architect outside of working hours. P. Egas was the first City Council member to present this problem. His opinion was supported by other members including A. van Dorsten, A. Weeber, F.H. Johan, and C.F.M. Verstijnen. Furthermore, Van Dorsten also proposed that the same treatment be given to members of the Technical and Development Commissions given that they held the same level of the position as Citroen with access to important secret documents of the Municipality (Anonymous, May 31, 1916).

The president promised to pay attention to this issue. He also replied that Citroen would probably be allowed to practice privately with the knowledge and permission of the president or his superintendent while acknowledging that it would be difficult to monitor his activities as requested by J.W. van der Spek. He added that Citroen should be treated the same as other civil servants with the freedom to work outside office hours. If Citroen were not allowed to practice privately, it was possible he would ask for a higher salary. The President's opinion was supported by A. de Mooy. He assigned a project in the Municipality of Semarang, the development plan of which was made by the private architectural bureau of Henri Maclaine Pont (Anonymous, May 31, 1916).

The president's opinion was responded to positively by council member A. Weeber. He preferred for Citroen to work exclusively for the Municipality with a higher salary, banning him from independent projects. His opinion was backed up by P. Egas and he suggested making salary negotiations with Citroen. At last, the proposal for Citroen's contract was voted on, resulting in sixteen members approving and two members refusing. The result was sent to Citroen in a letter from the City Council president No. 3892/16 dated June 5, 1916. The content included a plan for the Municipal Works, which was approved by the City Council, to extend Citroen's service to the Municipality as well as the Municipal offers regarding salary, working hours and the prohibition to work privately outside of office hours (Anonymous, May 31, 1916). Citroen was asked to respond as soon as possible (Anonymous, June 21, 1916).

Citroen replied by letter dated June 6,1916 . He refused the prohibition to work privately because it threatened his future career prospects. In the event of an emergency in the Municipality, he could be discharged from his job, rendering him jobless. He proposed to be permitted to work privately, under normal conditions, with permission from the president of the City Council, a request usually granted by the Mayor of Surabaya. He indicated that other civil servants had the freedom to work privately outside official working hours and that the Municipality was obliged to treat its civil servants equally. He understood the argument regarding the prohibition of independent projects if it was only applied in the event of an emergency or dangerous situation (Anonymous, June 21, 1916). 
Furthermore, Citroen commissioned Thomas Karsten's projects in Semarang, H.P. Berlage's ones in Batavia, Amsterdam, and The Hague. People trust wellknown architects with good reputations in their architectural bureaus to make development plans for their cities and other projects. By working privately, Citroen wanted to be a trusted consultant, not only with the Municipality but also with other clients. He ended his letter with the request that the City Council remove the prohibition mentioned above so that he could continue the Municipal projects assigned to him (Anonymous, June 21, 1916).

After receiving Citroen's reply, L.J. Schippers conducted informal meetings and negotiations with Citroen and each of the commissions involved with the matter, i.e. the Financial, Technical and Development Commissions. The result was reported to the City Council in a letter No. 4088/16 dated June 16, 1916, with the following considerations:

1. Citroen's prohibition to practice privately presents obstacles in his service to the Municipality;

2. his office working hours are changed to 07.00 to 12.00 ; and

3. all commissions suggest that for the sake of the Municipality, Citroen should be approached as a skilled architect who is expected to make development plans for Surabaya and the design of the Town Hall (Anonymous, June 21, 1916).

Finally, Schippers proposed the following decision to the City Council:

1. salary of $f 500$ per month to be paid from May 1, 1916, except June;

2. official working hours for Citroen to be 07.00 to 12.00 every day;

3. Citroen would be allowed to practice privately (for non-Municipal projects) as long as each project was approved separately by the president; and

4. when construction of the Town Hall started, Citroen would be released from service to the Municipality and the monthly salary would be stopped, but he would receive a $5 \%$ commission fee for total building costs (Anonymous, June 21, 1916).

On June 21, 1916, the City Council held a meeting which included the extension of Citroen's service to the Municipality on the agenda. Councilmember J.M.I. Says questioned the sequence of articles in the contract. According to him, articles on working hours and permission to work privately should be put before articles on salary and period of service. This suggestion was agreed to by the president. Says expressed his objection to the 5\% compensation for total building costs of the Town Hall. He proposed that Citroen should receive only his total salary for all of his work. The president explained that the 5\% fee as compensation for the supervision of the Town Hall construction, not for the development of the design, and that the fee was fair for such activities. The fee percentage was based on advice from the Technical Commission. Says explained that Citroen was also assigned to other projects for which he did not receive an additional fee. Council members J. Hekket and J.F.A.M. Buffart supported the president's opinion. Based on information received by Hekket, a $5 \%$ fee was too small. According to P. Egas, supervisors usually receive $10 \%$ of building costs (Anonymous, June 21, 1916).

Additional problems concerning the wording of text were addressed at the meeting. Buffet proposed that a draft agreement should be proposed to the legislative commission and afterward forwarded to a notary public to make it 
official. The president accepted Buffart's suggestion. Finally, council member J.W. van der Spek asked the council to make a decision soon regarding Citroen's service which was approved by the president. After the vote, seventeen members accepted the terms of the agreement with only one member refusing (Anonymous, June 21, 1916).

What happened after the meeting is unknown because of the limited documentation. However, on October 28, 1918, two years after the meeting, the City Council held a meeting wherein a proposal concerning the appointment of an architect into the service of the Municipality was included on the agenda. The meeting was led by A. Meyroos, the first Mayor of Surabaya. At this meeting, J. Hekket agreed that Citroen would be put in charge of town development plans and housing construction. He also agreed with the opinion of the Director of the Municipal Works that the two matters were separate from the job description outlined by the Municipal Works because the organization had become involved with a variety of projects and its progress was too slow. In his opinion, the appointed architect should not be placed under the Director of this organization. Furthermore, Hekket proposed establishing an independent branch led by someone who was solely accountable to the City Council directly. If an architect was placed in that position, he should not be independent and he would be under the control of the Director of the Municipal Works (Anonymous, October 28, 1918).

Buffet, chairman of the Grondbedrijfcommissie (Commission of Development Company), refused the idea of decentralization proposed by J. Hekket arguing that drainage, sewerage, and town development were related to each other, requiring an expert who understood such challenges completely. Also, Hekket's comment about slowness was only applicable to the construction of low-cost housing for indigene (Anonymous, October 28, 1918).

The president had not found proper reasons to accept Hekket's suggestion. In Batavia, the Town Development Department was incorporated by the rooiwezen (building inspector). According to him, town development was related to the Municipal Works Department. He also suggested that the construction of housing by private companies was faster. Finally, a decision was determined by vote, resulting in eleven members approving and only one member refusing (Anonymous, October 28, 1918).

After construction of the Town Hall was finished in 1927, the Municipality wanted to renew the contract with Citroen because the previous contract did not match the situation of the Municipality, especially with the projects planned, designed and built by the Municipal Public Works. This dates back to content from the Municipal Sheet No. 37, dated January 28, 1927, which mentions in the introduction the idea to ask Citroen to reassign as the advisory architect. This idea emerged because there was an objection to the results of a design competition held by the Municipality for the construction of a fire department building (Anonymous, January 28, 1927). Citroen was hired to oversee the Municipal projects. His contribution was also still needed for the Municipality to complete the New Town Hall. There were several complementary buildings which had not yet been designed or constructed. 
The technical commission supported a plan to reactivate Citroen in the Municipality service and asked the new Mayor, G.J. Dijkerman, to propose a contract of agreement. After the contract was finalized, the Municipality forwarded it to the City Council. Content of the agreement included the following (Anonymous, January 28, 1927):

1. Citroen would receive a salary of $f 500$ per month for his role as the advisory architect for the following projects:

a. town planning projects including designs for suitable housing types,

b. the development of low-income housing projects and kampung,

c. buildings for the Municipality, including bridges, etc.,

d. layout for public parks and their complement buildings, such as kiosks, music marquees, etc;

2. Citroen would be in charge of any elaboration of plans according to advice and sketches have given;

3. At the request of the Mayor, he would attend meetings if his opinion were needed;

4. Citroen, as an advisory architect, was asked explicitly to:

a. continue and complete the Town Hall he designed,

b. design and oversee the execution of large buildings ("omvangrijke bouwwerken");

5. For those activities mentioned above, Citroen would receive a fee according to the class of Bond van Nederlandse Architecten (Association of Netherlands Architects) scales (Indisch tarief) which was lower than the normal fee for similar works;

6. All potential disputes following the agreement between Citroen and the Municipality would be subject to the discretion of three arbitrators, who would be appointed by parties in mutual consultation;

7. The costs of arbitration would be borne by the unsuccessful party unless the arbitration committee required a breakdown of costs; and

8. The agreement would commence on the day of its signature and would last for a year, which would always be extended tacitly by one year.

On February 3, 1927, the City Council held a meeting to discuss the list of agreements mentioned above. To propose clear and specific, council member Tichelaar proposed to replace the word "omvangrijk" (large) with another appropriate word. His opinion was supported by council member V.W.Ch. Plowman who suggested the word "belangrijk" (important). Finally, the Mayor agreed to this modification and no further refusals were made (Anonymous, February 3, 1927).

Councilmember W.M. Naessens asked whether Citroen was the only qualified architect. The Mayor did not answer the question, but he explained that the Mayor and the aldermen considered him to be the right person. Naessens was not satisfied with the Mayor's statement. V.W.Ch. Plowman observed that Citroen had previous experience with the Municipality. Councilmember Nessel van Lissa added that Citroen had made development plans, designed public housing, etc. Both members supported Citroen's appointment as the advisory architect. However, council member Moerbanoe Kartodirdjo refused the proposal because in his opinion the Municipality already had enough engineers to do the works mentioned in the terms 
of the agreement. Finally, without voting, the City Council decided to accept the proposal with the annotation that Moerbanoe disagreed with it (Anonymous, February 3, 1927).

On June 26, 1929, the City Council held a meeting, led by H.I. Bussemaker as a president. The agenda included the contract between Citroen and the Municipality, as recorded on the Municipal Sheet 1929 No. 144. Councilmember C.P.J. van Koetsveld expressed his objection to the contract. Each year, the Municipality was to spend $f 6,000$ for the advisory architect (Citroen), but the content of the previous agreement, signed on February 19, 1927, which included development plans, the construction of small housing and kampung, bridges and town parks, was not effectively applied. Although Citroen was supposed to advise on housing construction conducted by the $N V$. Volkshuisvesting as mentioned in the agreement or the Municipal Sheet No. 37 in February 1927, apparently the company had appointed its architect. Also, the construction of small housing carried out by the Municipality was designed by employees of the Municipality itself without advice from Citroen. For the Wonokromo Bridge project, Citroen received an extra fee of $f$ 4,000 which was not stipulated in the agreement. Van Koetsveld thought that architectural expertise was not needed for the design of town parks. In general, they were all confused because the content of the previous agreement was not agreed to by Citroen. The unauthorized agreement was upheld because of weaknesses within the Municipal supervision, lack of coordination between the Municipality and its different departments (including its independent department, i.e. $N V$. Volkshuisvesting) and the business dealings of Citroen himself. Therefore, Van Koetsveld asked the Mayor to present all data related to Citroen's activities and to temporarily withdraw the contract with Citroen from the agenda of the meeting (Anonymous, June 26, 1929).

Councilmember V.W.Ch. Plowman revealed that in actuality, the Municipality spent $f 1,300$ per month: $f 500$ for Citroen and $f 800$ for Bruno Nobile de Vistaprint. According to Ploegman, it was possible to merge the role of both architects by appointing a new Municipal employee who had a background in architectural engineering while council member C.H.P. Jagtman considered the contract to be excessive. In the following year, the focus of the Municipality was on kampung improvement, not on the construction of large architectural projects. If architectural advice was needed, the Municipality would consult one of the many experts in the Netherlands Indies or hold a design competition. The president closed the meeting by promising to provide complete data on Citroen's activities and the contract proposal was returned to the college of the Mayor and aldermen (Anonymous, June 26, 1929).

Almost two months later, the Municipality released the Municipal Sheet No. 242, dated August 8,1929, which stated that the contract between the Municipality and Citroen, dated February 19, 1927, would be ended on February 19, 1930 (Anonymous, August 8, 1929). This decision was approved by the City Council at its meeting on the same date without discussion or a vote (Anonymous, August 14, 1929).

To implement Ploegman's idea, the Municipality released the Municipal Sheet No. 257 dated September 25, 1929, designating an architectural engineer to be 
the superintendent head of housing and construction. The engineer was to be put in charge of the formation of Service Group II - Public Works.

\section{Citroen's Works}

During his career in the Netherlands Indies, Citroen involved in several projects, from architectural design to civil construction and furniture to town planning. The majority of the works are in Surabaya, and the rest are in Malang and Jember. Santoso (2013) mentions in detail the works of Citroen. In Surabaya, they are a development plan for the Kupang area (1915), a development plan for the Ketabang area (1916), Surabaya town hall (1916-1925), a house on Sumatra street (1916), Kebondalem bridge (1917), Bataafsche Petroleum Maatschappij (BPM) office (1917), "K.K. Knies" music and piano shop (1917), a shop of "Van Kempen, Begeer and Vos" Royal Dutch precious metal company (1917), Darmo hospital (1919), Gubeng bridge (1922), the ninth Surabaya annual fair (before end of July 1923), Pasar Besar railway viaduct (before September 1923), an extension of the Algemeen Syndicaat van Suikerfabrikanten in Nederlandsch-Indië (ASNI) building (1925), a British community church (1926), an emplacement of the BPM (1927), Wonokromo bridge (March 1928), a mansion on Kayun street (after March 1928), Surabaya mayor's official residence (end of 1928), a monument of Dijkerman (1st semester of 1929), and Borneo Sumatra Handel Maatschappij (Borsumij) office (1930). Before December 1925, he produced three design drawings for a wooden gasoline station, a wooden boathouse, and a wooden restaurant in a town park.

In Malang, he designed a country house, Lawang (1916), an interior of Malang town hall (1927), and a "Faroka" cigarette factory (after mid of June 1931), while in Jember he produced the design for a hospital (1931).

\section{CONCLUSIONS}

Citroen started to work for the Municipality of Surabaya on April 15, 1915. The Municipality needs an urban planner to handle the development plan for the Kupang area, at a time when there was a shortage of urban planners in the Netherlands Indies. The contract lasted for a year and ended on April 15, 1916. This period is an assessment period of Citroen's competence by the Surabaya Municipality.

The second contract began on May 1, 1916, to 1927, and the third or the last one started from February 19, 1927, up to February 19, 1930. These are believed as a continuous contract with no lag time. During this period which lasted more than 13 years, Citroen is trusted to handle a variety of projects. It means that he acts as a full independent architect in two periods, i.e April 16-30, 1915 and February 20, 1930, onwards.

Citroen's career in Surabaya was greatly influenced by G.J. Dijkerman (18851929) who was the Mayor of the city from 1920 to 1929. Dickerman helped Citroen by introducing him to other 'parties' and promoting him actively so that Citroen's network expanded, particularly during the period of Dijkerman's leadership. The project of the Pasar Besar railway viaduct and probably the interior of the Malang 
Town Hall are examples of Dijkerman's involvement. It is therefore not surprising that when Dijkerman died Citroen was asked to design a monument to him. Dijkerman's death indirectly led to the termination of Citroen's contract with the Municipality, as he now lacked sufficient backing.

There were two reasons why the Municipality did not extend the contract for the fourth time. Firstly, the use of architects in the Municipality and its independent services was not efficient, especially in the time of the Great Depression (the late 1920s decade). Two different positions were occupied by two different architects, i.e. Citroen and De Vistarini, who had essentially the same function. Secondly, Citroen's advisory role in the Municipal projects as mentioned in the agreement was not optimal.

During the first period as the municipal architect, Citroen designed a development plan for the Kupang area, a development plan for the Ketabang area, and the initial design of Surabaya town hall (April 1916).

Citroen involved in various designs, both for the Municipality and for private clients, in the second contract. For the municipality, he created five designs, i.e Surabaya town hall (end of 1916, ca. 1918-1925), Kebondalem Bridge, Gubeng Bridge, the ninth Surabaya annual fair, and Pasar Besar railway viaduct. While for private clients, Citroen made more designs in the afternoon or after office hours. They cover a house on Sumatra Street, a country house, BPM office, "K.K. Knies" shop, "Van Kempen, Begeer and Vos" shop, Darmo hospital, an extension of the ASNI building, and a British community church.

In the third contract, Citroen created four designs for the municipality, as follows: Wonokromo Bridge, mayor's official residence, Dijkerman monument, and a drawing of a wooden restaurant in a town park. While in the afternoon, he designed for the private clients, namely: an emplacement of the BPM, an interior of Malang town hall, a mansion on Kayun Street, design drawings for a wooden gasoline station and a wooden boathouse.

Upon termination of the contract with the municipality, Citroen acts as an independent or a private architect until his death. During this period, he designed the Borsumij office, a hospital in Jember, and a "Faroka" cigarette factory.

For Citroen, the opportunity to design for private clients provides more flexibility, both in terms of cost and design, so that he was able to produce works that were better than those for the city government. Tan Tjwan Bie's mansion and Borsumij office are the best examples of works for private clients and the town hall is the best example of work for the government.

Tan Tjwan Bie's mansion was designed by Citroen, assisted by Gerard Pieter Adolfs (1898-1968) who designed the mural and was constructed by Nederlandsch Aanneming Maatschappij (Nedam). With his financial capabilities as founder and owner of a sugar factory, Tan Tjwan Bie was able to hire Citroen as one of the best architects in Surabaya and the Netherlands Indies, Adolfs as a painter with an international reputation, and Nedam as a well-known contractor in the colony. The result is a mansion in a hybrid modern architecture (a mixture of Art Deco, Amsterdam School, and De Stijl) that uses the best quality material in its class.

The Borsumij office with the Nieuwe Bouwen style is considered as the best work in terms of spatial system and lighting (Lemei, 1935). This was also 
acknowledged by the representative head of Borsumij so that when Borsumij would build its office in Semarang, he asked the architect J.F.L. Blankenberg in 1938 to pay attention to these two things by referring to the work of Citroen in Surabaya. In the end, the two buildings owned by the same company had similarities in design even though they were designed by different architects.

Surabaya town hall is the best work of Citroen for the city government although he faced several constraints. At least, he took nine years to complete the design. There are three reasons why this can happen. First, there is a change in location. Initially, the town hall was designed in the town park site, opposite the Kebonrojo post office (now occupied by Bank Indonesia building), but then moved to Ketabang, which was planned to be the location of the new city government center. Second, city council members criticized the initial design of the town hall which had European style and did not reflect the local vernacular architecture. And third, there were budget constraints that lead to the simplification of city hall design. Finally, the existing town hall is the rear part of the design that should be.

\section{ACKNOWLEDGEMENT}

This article is a part of research funded by the Ford Foundation through the International Fellowships Program (IFP) scheme.

\section{REFERENCES}

Anonymous, (1916) Gemeenteblad van Soerabaja, No. 99, April 15, 1916. , (1916) Gemeenteblad van Soerabaja, No. 128, May 31, 1916. , (1916) Gemeenteblad van Soerabaja, No. 141, June 21, 1916. , (1916) Notulen van de Openbare Vergadering van den Gemeenteraad van Soerabaja, May 31, 1916.

, (1916) Notulen van de Openbare Vergadering van den Gemeenteraad van Soerabaja, June 21, 1916.

, (1918) Notulen van de Openbare Vergadering van den Gemeenteraad van Soerabaja, October 28, 1918.

, (1927) Gemeenteblad van Soerabaja, No. 37, January 28, 1927.

, (1927) Notulen van de Openbare Vergadering van den Gemeenteraad van Soerabaja, February 3, 1927.

, (1929) Gemeenteblad van Soerabaja, No. 242, August 8, 1929.

, (1929) Gemeenteblad van Soerabaja, No. 257, September 25, 1929.

, (1929) Notulen van de Openbare Vergadering van de Gemeenteraad van Soerabaja, June 26, 1929.

, (1929) Notulen van de Openbare Vergadering van den Gemeenteraad van Soerabaja, August 14, 1929.

Berlage, H.P . (1931) Mijn Indische Reis, Gedachten over Cultuur en Kunst, W.L. \& J. Brusse's, Rotterdam.

de Zeeuw, W. (2001) Cosman Citroen 1881-1935, typescript, NAi, Rotterdam. 
Lemei, W. (1935) Architect C. Citroen BNA, Indisch Bouwkundig Tijdschrift Locale Techniek, 5(4), September 1935, 2-9.

Santoso, J. T. (2013) Architect Cosman Citroen (1881-1935), Family Background, Arrival to- and Career in Surabaya, Dimensi, 40(1), July 2013, 19-25. 